\title{
Komparasi Hasil Belajar pada Pembelajaran Fisika Materi Gerak Lurus Siswa Kelas X SMA Negeri 1 Belitang
}

\author{
${ }^{1}$ Effendi, ${ }^{2}$ Mar'atus Sholikhah \\ 1,2 Program Studi Pendidikan Fisika STKIP Nurul Huda Sukaraja \\ ‘E-mail: ${ }^{1}$ effendi@stkipnurulhuda.ac.id ${ }^{2}$ maratussholikhah1707@gmail.com
}

\begin{abstract}
Abstrak
Penelitian ini berupaya untuk mengetahui sejauh mana perbedaan hasil belajar Fisika yang dalam pembelajarannya menerapkan metode Snowball Throwing dan metode Talking Stick di SMA Negeri 1 Belitang. Adapun Populasi dalam penelitian ini meliputi seluruh siswa kelas X di SMA Negeri 1 Belitang OKU Timur. Teknik pengambilan sampel dalam penelitian ini dengan cara acak. Kelas yang terpilih akan digunakan sebagai kelas eksperimen I dan kelas eksperimen II. Adapun teknik pengumpulan data yang dggunakan yakni tes, sedangkan untuk menguji hipotesis menggunakan uji-z. Sesuai dengan pengolahan data yang dilakukan diperoleh nilai rata-rata kelas eksperimen I sebesar 82,00 dan nilai rata-rata kelas eksperimen II sebesar 69,33. Sehingga dapat disimpulkan terdapat perbandingan hasil belajar Fisika yang signifikan antara siswa yang pembelajarannya menggunakan metode Snowball Throwing dengan metode pembelajaran Talking Stick pada materi Gerak Lurus kelas X di SMA Negeri 1 Belitang, sebab nilai $Z_{\text {hit }}=7,08$ tidak terletak antara $-1,96$ dan 1,96, sehingga $\mathrm{H}_{\mathrm{o}}$ ditolak dan $\mathrm{H}_{\mathrm{a}}$ diterima.
\end{abstract}

Kata kunci: Metode pembelajaran, Snowball Throwing, Talking Stick, Hasil Belajar.

\section{PENDAHULUAN}

Mutu atau kualitas pendidikan suatu negara dapat dilihat dari bagaimana Kualitas Sumber Daya Manusia yang dimilikinya. Sebab pendidikan merupakan salah satu unsur penting bagi proses kehidupan manusia, karena melalui proses pendidikan akan dapat menciptakan sumber daya manusia yang unggul dan berkualitas. Dalam praktiknya dapat dikatakan semua negara memposisikan pendidikan sebagai objek utama yang mampu menopang keberlangsungan pembangunan bangsa dan kemajuan suatu negara. Melalui pelaksanaan proses pendidikan maka kehidupan manusia akan tercerahkan, dalam kata lain kemajuan pendidikan yang mengarah pada proses pembentukan kelimuan manusia akan mampu menjalani proses kehidupan sesuai dengan keadaan zaman. Pendidikan yang berkualitas mampu melahirkan manusia yang siap untuk hidup di masyarakat.

Proses pendidikan diawali dari adanya siswa yang siap untuk melaksanakan aktivitas belajar. Sebab menurut Skinner belajar merupakan suatu perilaku pada saat orang belajar, maka responsnya menjadi lebih baik, sebaliknya bila tidak belajar maka responsnya menurun (Dimyati, 2015:9) Dalam berproses siswa harus mampu mengikuti rangkaian kegiatan dalam pembelajaran. Sehingga manakala proses yang terjadi sudah efektif maka hasil belajar yang didapatpun akan maksimal. Salah satu langkah dalam mewujudkan tujuan pendidikan yakni dengan adanya proses kegiatan pembelajaran di sekolah baik secara formal maupun informal.

Gagne berpendapat bahwa pembelajaran merupakan proses pengaturan peristiwa secara seksama dengan maksud terjadinya belajar dan membuatnya berhasil guna (Siregar, 2017:12). Kegiatan pembelajaran dilakaukan sebagai langkah untuk mencapai tujuan pendidikan. Sebab dalam istilah psikologi berkaitan erat dengan segi pengetahuan dan dapat menimbulkan perubahan baik dari tingkah laku, kepandaian, dan lain-lain yang berasal dari pengalaman seseorang yang berhubungan dengan ranah kognitif, afektif, dan psikomotorik.

Unsur yang paling penting dalam proses pembelajaran salah satunya adalah harus adanya pendidik. Syarat menjadi seorang pendidik adalah mampu mengembangkan kemampuan dirinya agar 
memiliki pengetahuan dan keterampilan sehingga nantinya akan menciptakan proses pembelajaran yang bermakna bagi peserta didik. Pendidik dalam kegiatan pembelajaran harus dapat menyajikan materi pembelajaran sesuai dengan kurikulum dalam menentukan materi pembelajaran dengan kategori relevan pencapaian Standar Kompetensi (SK) dan pencapaian Kompetensi Dasar (KD), konsisten, kecukupan. Hamalik (2011: 57) memberikan inforamasi bahwa salah satu ciri pembelajaran yakni adanya rencana, saling ketergantungan dan adanya tujuan. Jika pendidik belum dapat melakukan proses pembelajaran secara optimal, maka proses pembelajaran akan sulit mencapai tujuan pembelajaran yang ditetapkan. Artinya pada suatu kondisi, pendidik harus mampu memperhatikan posisi metode pembelajaran agar dapat melibatkan siswa secara aktif dalam proses kegiatan pembelajaran yang dilakukan. Disisi lain terkadang jadwal belajar yang ditentukan belum sesuai dengan kondisi siswa dan lingkungan, dimana terdapat peserta didik yang mengikuti kegiatan belajar pada jam yang tidak efektif, hal ini tentu akan menyebabkan pembelajaran kurang efektif berakibat pada rendahnya hasil belajar peserta didik.

Peserta didik merupakan anak didik yang mengalami proses perubahan dalam perkembangan perilakunya, jelas hal ini memerlukan bimbingan atau arahan dalam membentuk kepribadian. Dalam proses pembelajaran peserta didik termasuk dalam subjek belajar yang harus menguasai materi dari bahan ajar melalui sebuah proses pembelajaran. Untuk menjadi seorang pendidik memang harus memperhatikan tingkat kemampuan peserta didik, karena setiap peserta didik mempunyai tingkat kemampuan yang berbeda-beda dalam proses pembelajaran di kelas, dengan perbedaan yang terdapat dalam diri peserta didik, maka akan ada perbedaan kemampuan dalam menyerap ilmu yang diberikan oleh pendidik. Bloom mendefinisikan bahwa hasil belajar peserta didik terdapat dalam ranah kognitif, afektif dan ranah psikomotorik (Ansori, 2008:49). Oleh karena itu setiap individu peserta didik memiliki karakteristik dan cara yang beragam dalam memperoleh informasi, karena perbedaan inilah seorang guru dituntut agar dapat memberikan proses pembelajaran yang tepat sesuai dengan perbedaan tersebut. Pendidik dituntut dapat mengembangkan pola pembelajaran yang lebih kreatif, menerapkan dan mengembangkan metode pembelajaran yang lebih bervariasi, sehingga hal ini akan membantu tercapainya tujuan pembelajaran yang telah ditetapkan. Sebab Metode adalah suatu cara untuk menyampaikan pesan-pesan pembelajaran (Arsyad, 2007:4).

Kegagalan seorang pendidik dalam kegiatan pembelajaran bukan hanya dikarenakan tidak menguasai bahan atau materi pembelajaran tetapi kurang menguasai penggunaan metode pembelajaran. Pendidik cenderung menggunakan metode pembelajaran konvensional yang masih berpusat pada pendidik. Tentu hal inilah yang menyebabkan siswa cenderung malas untuk berfikir, yang berakibat pada rendahnya hasil belajar siswa. Pemilihan metode pembelajaran yang tepat dan sesuai akan mampu memperjelas konsep teori yang diberikan guru. Pemilihan metode pembelajaran secara khusus harus mengacu pada tujuan pembelajaran yang telah dirumuskan. Sebab tujuan pembelajaran yang jelas akan memudahkan guru dalam melaksanakan proses pembelajaran.

Berdasarkan masalah yang terjadi, peneliti akan menggunakan metode pembelajaran yang efektif, inovatif dan kreatif. Penerapan metode pembelajaran Snowball Throwing dan metode pembelajaran Talking Stick akan banyak menuntut peserta didik untuk mengembangkan kemampuan bekerja sama dan berkomunikasi dengan aktif dalam menyampaikan pendapat ataupun bertanya, baik dalam melibatkan benda-benda konkret dan maupun yang abstrak. Hamdayana (2017:161) mengatakan bahwa metode Snowball Throwing mampu membuat Suasana pembelajaran menjadi menyenangkan karena peserta didik seperti bermain dengan melempar bola kertas kepada peserta didik lain. Munawaroh (2014) Model Snowball Throwing ini berguna untuk melatih siswa agar lebih tanggap dalam menerima pesan dari siswa lainnya yang berbentuk bola salju kertas, dan menyampaikan pesan tersebut kepada temannya dalam satu kelompok. Dalam hal ini peranan guru hanya sebagai pemberi arahan kepada siswa mengenai topik pembelajaran dan mengatur jalannya pembelajaran

Sedangkan metode pembelajaran Talking Stick menurut Huda (2013:227) mampu menguji kesiapan peserta didik dan melatih keterampilan peserta didik dalam membaca dan memahami materi 
pelajaran dengan cepat. Secara spesifik kedua metode pembelajaran ini memiliki perbedaan dalam hasil belajar dari sumber yang berorientasi pada belajar kelompok. Metode pembelajaran Snowball Throwing menyajikan pertanyaan dalam bentuk gulungan kertas yang dibuat oleh peserta didik, kemudian peserta didik lain menjawab pertanyaan yang tertera dalam kertas. Sedangkan metode pembelajaran Talking Stick secara khusus pertanyan dibuat oleh pendidik dan diberikan kepada peserta didik yang memegang tongkat dan peserta didik harus menjawab pertanyaan tersebut. Kenyataan di lapangan menunjukkan bahwa Informasi yang berkaitan dengan hasil belajar peserta didik kelas X pelajaran IPA Fisika masih rendah terutama dalam materi Gerak Lurus. Karena banyaknya konsep pada materi Gerak Lurus, serta banyaknya persamaan yang harus dipahami, maka pendidik perlu menerapkan atau menggunakan metode pembelajaran yang sesuai dengan materi, hal ini menyebabkan hasil penilaian harian peserta didik tidak mencapai standar KBM (Ketuntasan Belajar Minimal) yang telah ditetapkan. Hasil penilaian harian peserta didik pada mata pelajaran Fisika kelas $X$ di SMA Negeri 1 Belitang memiliki 65,71 \% di bawah nilai KBM. Proses pembelajaran yang dilakukan pendidik dikatakan efektif apabila hasil belajar dan aktivitas peserta didik yang diajarkan diharapkan dapat memenuhi KBM yang telah ditetapkan sekolah.

Berhasilnya proses pembelajaran yang dilakukan pendidik tidak hanya karena pemilihan metode pembelajaran ataupun materi yang disampaikan yang dapat mempengaruhi hasil belajar peserta didik. Seperti halnya permasalahan yang telah dijelaskan, tetapi juga keadaan peserta didik kelas $X$ di SMA Negeri 1 Belitang dalam mengikuti kegiatan pembelajaran terlihat masih kurangnya persiapan. Beberapa siswa masih belum dapat fokus pada kegiatan yang dilakukan, hal ini nampak dari masih rendahnya respon yang diberikan disaat guru menjelaslkan materi pembelajaran. Berdasarkan pada kondisi tersebut, maka guru perlu merancang desain dalam bentuk metode pembelajaran yang aktif, inovatif dan kreatif, bukan hanya menyampaikan materi pelajaran secara verbal agar cepat habis, tetapi harus mampu mengajak siswa untuk meningkatkan kemampuan berfikirnya. Oleh karena itu yang menjadi titik fokus peneliti memilih pembelajaran Fisika dengan metode pembelajaran Snowball Throwing dan metode pembelajaran Talking Stick, karena metode tersebut berorientasi kemampuan kerja kelompok dibandingkan individu. Selain itu metode tersebut sangat menggembirakan, sehingga peserta didik tidak tegang dan mudah termotivasi untuk belajar. Pada akhirnya perubahan belajar yang bersifat positif dan aktif dapat terwujud (Slameto, 2010: 15).

\section{METODE/EKSPERIMEN}

Jenis penelitian termasuk penelitian kuantitatif. Penelitian dengan menggunakan metode kuantitatif jenis komparatif ini tidak terjadi manipulasi data dari peneliti, hingga datanya benar-benar akurat dengan melakukan teknik pengumpulan data. Hasil dari data tersebut dapat dianalisis secara statistik untuk mencari suatu perbedaan variabel yang diteliti.

Desain Penelitian yang digunakan adalah The Post Test-Only Control Group Design. Secara diagram rancangan penelitian ini digambarkan pada Tabel 1.

Tabel 1. Pemberian perlakuan The Post Test-Only Control Group Design

\begin{tabular}{ccc}
\hline Kelas & Perlakuan & Posttest \\
\hline Eksperimen I & $\mathrm{X}_{1}$ & $\mathrm{O}_{2}$ \\
Eksperimen II & $\mathrm{X}_{2}$ & $\mathrm{O}_{2}$ \\
\hline
\end{tabular}

Dalam pelaksnaannya penelitian ini dilakukan pada dua kelas, yaitu kelas eksperimen I yang menerapkan metode pembelajaran Snowball Throwing dan eksperimen II menerapkan metode pembelajaran Talking Stick. Desain tersebut terdapat dua kelompok yang dipilih secara jenuh, kemudian diberi post test untuk mengetahui adakah perbedaan antara kelompok eksperimen I dan kelompok eksperimen II. Populasi dalam penelitian ini adalah seluruh peserta didik dari kelas X SMA Negeri 1 Belitang yang berjumlah 216 peserta didik. Sampel yang terpilih adalah pesera didik kelas $X$ 
IPA 3 sebagai kelas eksperimen I yang diberi perlakuan metode pembelajaran Snowball Throwing dan kelas X IPA 6 sebagai kelas eksperimen II yang diberi perlakuan metode pembelajaran Talking Stick.

Terdapat dua vareabel dalam penelitian ini, yaitu variabel bebas dan variabel terikat. Variabel bebas dalam penelitian ini adalah metode pembelajaran Snowball Throwing dan metode pembelajaran Talking Stick. Sedangkan variabel terikatnya adalah hasil belajar Fisika peserta didik pada materi Gerak Lurus kelas X di SMA Negeri 1 Belitang tahun pembelajaran 2019/2020.

Dalam pengumpulan data dengan teknik tes. Sebab menurut Arikunto (2010:193) Tes adalah serentetan pertanyaan atau latihan yang digunakan untuk mengukur keterampilan, pengetahuan, intelegensi, kemampuan bakat yang dimiliki oleh individu atau kelompok. Peserta didik kelas eksperimen I dan kelas eksperimen II diberikan soal berbentuk tes pilihan ganda berupa 25 (dua puluh lima) pertanyaan yang harus dijawab oleh peserta didik. Tes yang digunakan dalam penelitian ini sesuai dengan indikator materi mengenai Gerak Lurus.

Teknik Analisis instrumen dilakukan untuk mengetahui tingkat validitas instrumen, reliabilitas instrumen, tingkat kesukaran instrumen dan daya pembeda instrumen yang tujuannya untuk mengetahui layak atau tidaknya soal tes hasil belajar untuk dilanjutkan dalam penelitian. Adapun dalam pengujian validitas menggunakan persamaan dalam Sugiyono, (2009:183).

Teknik Analisis data Pengumpulan data dalam penelitian ini dilakukan dengan cara pemberian soal tes hasil hasil belajar kepada peserta didik setelah peserta didik menerima perlakuan dari kegiatan pembelajarannya. Tes dilakukan pada kelas eksperimen I dengan menggunakan metode pembelajaran Snowball Throwing dan kelas eksperimen II dengan menggunakan metode pembelajaran Talking Stick yang dilakukan pada akhir pertemuan berupa post test. Hasil pemberian tes tersebut selanjutnya dilakukan kegiatan pengolahan data dan analisis data yang pada akhirnya pada kegiatan pengujian hipotesis.

\section{HASIL DAN PEMBAHASAN}

Hasil

Proses pembelajaran dilakukan dengan menerapkan metode pembelajaran Snowball Throwing yaitu Kelas X IPA 3 sebagai kelas eksperimen I dan kelas X IPA 6 sebagai kelas eksperimen II yang diberi perlakuan metode pembelajaran Talking Stick. Pendidik memberikan soal hasil belajar dilakukan pada saat akhir pembelajaran setelah peserta didik diberi perlakuan dengan tujuan untuk mengetahui sejauh mana peserta didik memahami dan mengerti teori yang sudah dikerjakan.

Berdasarkan kegiatan uji validitas dan reliabilitas, dinyatakan 22 soal valid dan bersifat reliabel, sedangkan 3 soal tidak valid dan tidak reliabel. Hal ini dikarenakan 3 soal termasuk kedalam kategori daya pembeda jelek. Adapun untuk mengetahui skor tertinggi, skor terendah, rata-rata dan nilai standar deviasi ditunjukkan pada tabel 2.

Tabel 2. Data Hasil Posttest Peserta Didik

\begin{tabular}{ccccc}
\hline \multirow{2}{*}{ Kelas } & \multicolumn{2}{c}{ Skor } & \multirow{2}{*}{ Rata-rata } & SD \\
\cline { 2 - 3 } & Tertinggi & Terendah & & 82 \\
\hline Eks. I & 100 & 65 & 82,48 \\
Eks. II & 85 & 50 & 69,33 & 53,11 \\
\hline
\end{tabular}

Berdasarkan data pada tabel 2, kelas eksperimen I yang diberi perlakuan metode pembelajaran Snowball Throwing mendapat skor rata-rata lebih besar dibandingan kelas eksperimen II yang diberi perlakuan metode pembelajaran Talking Stick. Sedangkan kategori tinggi sedang dan rendah dapat dilihat pada tabel 3 . 
Tabel 3. Menentukan Kategori Tinggi, Sedang dan Rendah

\begin{tabular}{ccccc}
\hline \multirow{2}{*}{ Kategori } & \multicolumn{2}{c}{$\begin{array}{c}\text { Kelas Snowball } \\
\text { Throwing }\end{array}$} & \multicolumn{2}{c}{ Kelas Talking Stick } \\
\cline { 2 - 5 } & $\begin{array}{c}\text { Jumlah } \\
\text { Peserta } \\
\text { Didik }\end{array}$ & Persentase & $\begin{array}{c}\text { Jumlah } \\
\text { Peserta } \\
\text { Didik }\end{array}$ & Persentase \\
\hline Tinggi & 8 & $22,22 \%$ & 0 & $0 \%$ \\
Sedang & 27 & $75,00 \%$ & 22 & $61,11 \%$ \\
Rendah & 1 & $2,77 \%$ & 14 & $38,88 \%$ \\
\hline
\end{tabular}

Setelah didapatkan skor hasil belajar peserta didik, peneliti melakukan uji normalitas terhadap perolehan posttest peserta didik untuk mengetahui kenormalan data. Hasil uji normalitas pada kedua kelas kurang dari $X_{\text {tabel }} 11,07$ yaitu 6,53 kelas eksperimen I dan 5,75 kelas eksperimen II, maka data penelitian berdistribusi normal.

Setelah uji normalitas, maka dilakukan uji homogenitas untuk mengetahui apakah varian data adalah sama atau tidak. Hasil homogenitas dapat dilihat pada tabel 4.

Tabel 4. Hasil Uji Homogenitas

\begin{tabular}{ccc}
\hline $\boldsymbol{F}_{\text {tabel }}$ & $\mathbf{F}_{\text {hitung }}$ & Keputusan \\
\hline 1,76 & 1,17 & Homogen \\
\hline 4
\end{tabular}

Berdasarkan tabel 4 diatas maka dapat diketahui bahwa nilai $\mathrm{F}$ yang diperoleh dapat dilihat bahwa $F_{\text {hit }}<F_{\text {tabel }}=1,17<1,76$, maka Ha diterima. Dengan demikian dapat disimpulkan bahwa varian dalam penelitian ini adalah homogen.

\section{Pembahasan}

Dari kegiatan pengolahan data dan analisis data diperoleh bahwa peserta didik yang mendapat nilai dalam kategori tinggi untuk peserta didik yang pembelajarannya menggunakan metode pembelajaran Snowball Throwing persentasenya sebesar 22,22\% sedangkan peserta didik yang pembelajarannya menggunakan metode pembelajaran Talking Stick persentasenya sebesar 0\%. Peserta didik yang mendapat nilai dalam kategori sedang untuk peserta didik yang pembelajarannya menggunakan metode pembelajaran Snowball Throwing persentasenya sebesar $75,00 \%$ sedangkan peserta didik yang pembelajarannya menggunakan metode pembelajaran Talking Stick persentasenya sebesar $61,11 \%$. Hal ini menyatakan bahwa persentase pada pembelajaran yang menggunakan metode pembelajaran Snowball Throwing untuk kategori nilai sedang lebih besar dibandingkan yang pembelajarannya menggunakan metode pembelajaran Talking Stick.Sedangkan peserta didik yang mendapat nilai dalam kategori rendah untuk peserta didik yang pembelajarannya menggunakan metode pembelajaran Snowball Throwing persentasenya sebesar $2,77 \%$ sedangkan peserta didik yang pembelajarannya menggunakan metode pembelajaran Talking Stick persentasenya sebesar $38,88 \%$. Hal ini menyatakan bahwa persentase pada pembelajaran yang menggukanan metode pembelajaran Talking Stick untuk kategori nilai rendah lebih besar dibandingkan yang pembelajarannya menggunakan metode pembelajaran Snowball Throwing.

Perbedaan hasil belajar Fisika antara peserta didik yang pembelajarannya menggunakan metode pembelajaran Snowball Throwing dengan metode pembelajaran Talking Stick ditinjau dari rata-rata nilai hasil belajar peserta didik. Pada kelas yang pembelajarannya menggunakan metode pembelajaran Snowball Throwing diperoleh nilai rata-rata 82,00 dan kelas yang pembelajarannya menggunakan metode pembelajaran Talking Stick diperoleh nilai rata-rata 69,33. Jadi, dapat disimpulkan bahwa penggunaan 
metode pembelajaran Snowball Throwing lebih berhasil daripada penggunaan metode pembelajaran Talking Stick. Hal ini sepadan dengan Purbowo (2012) penerapan Pembelajaran Snowball Throwing berbantuan LKS efektif terhadap hasil belajar siswa kelas VIII SMP Negeri 1 Kaliori pada materi lingkaran.

Metode pembelajaran Snowball Throwing yakni proses pembelajaran yang berorientasi pada belajar kelompok, peserta didik diberi instruksi oleh pendidik tentang pembelajaran dan membentuk kelompok secara merata kemudian pendidik menjelaskan materi, setelah selesai maka setiap peserta didik diberikan selembar kertas untuk menulis satu pertanyaan yang berkaitan dengan materi yang telah disampaikan, kemudian kertas tersebut dibuat seperti bola dan dilempar dari satu peserta didik ke peserta didik lain, yang selanjutnya masing-masing peserta didik menjawab pertanyaan dari bola yang diperolehnya. Tujuan utama pembelajaran ini adalah melatih peserta didik untuk memiliki kreatifitas yang tinggi dan mampu berimajinasi dalam membuat pertanyaan, serta memacu peserta didik untuk saling bekerjasama, saling membantu, dan aktif dalam pembelajaran. Sedangkan metode pembelajaran Talking Stick mengajarkan cara berinteraksi yang berorientasi pada belajar kelompok, Tujuan utama metode pembelajaran Talking Stick yaitu dapat menciptakan suasana yang menyenangkan pada diri peserta didik, karena metode pembelajaran Talking Stick tidak hanya berisi soal-soal tetapi juga soal pengalihan dengan menggunakan iringan musik, sehingga membuat peserta didik rileks dan mengurangi rasa stres.

Berdasarkan dari proses pembelajaran kedua metode tersebut, dapat dilihat bahwa kelebihan dari penggunaan metode pembelajaran Snowball Throwing antara lain melatih peserta didik mengemukakan gagasan dan perasaan, dapat menumbuhkan potensi intelektual, sosial, dan emosional yang ada di dalam diri peserta didik. Namun dari segi kelebihan metode pembelajaran Snowball Throwing memiliki kelemahan antara lain kurang efektif digunakan untuk semua materi pelajaran, dan memerlukan banyak waktu untuk menyelesaikan proses pembelajaran yang menerapkan metode Snowball Throwing. Pada prinsipnya menurut Agustina (2013) Guru yang berkesan dalam menjalankan tugasnya adalah guru yang berhasil menjadikan siswanya termotivasi dalam pelajaran. Oleh karena itu guru harus berupaya untuk dapat menjadi jiwa yang menjadi motivator dalam pembelajaran.

Pembelajaran dengan menerapkan metode pembelajaran Talking Stick terdapat kelebihan dan kelemahannya sama halnya seperti penerapan metode pembelajaran Snowball Throwing. Adapun kelebihannya adalah dapat menciptakan suasana yang menyenangkan pada diri peserta didik, karena metode pembelajaran Talking Stick tidak hanya berisi soal-soal tetapi juga soal pengalihan dengan menggunakan iringan musik, sehingga membuat peserta didik rileks dan mengurangi rasa setres. Sedangkan kelemahan dari metode pembelajaran Talking Stick antara lain membuat suasanya kelas gaduh karena dengan adanya iringan musik atau nyanyian yang digunakan untuk melakukan estafet pada tongkat tersebut, memerlukan banyak waktu untuk menjawab pertanyaan yang diberikan pendidik apabila peserta didik memahami materi hanya sedikit. Faradita (2018) menjelaskan bahwa penggunaan model pembelajaran talking stick membuat siswa lebih bersemangat dan lebih cepat mengerti, hal ini terlihat ketika siswa mendapat tongkat dan mendapat pertanyaan, siswa cenderung menjawab pertanyaan secara langsung dengan pemikirannya sendiri bahkan ada juga yang menjawab pertanyaan dengan mendemonstrasikan secara langsung tanpa diminta. Yahya (2013) rata-rata hasil belajar antara siswa yang menggunakan model pembelajaran koperatif tipe Talking Stick lebih tinggi secara signifikan dibandingkan dengan siswa yang menggunakan model pembelajarankonvensional

Dari pembahasan kedua metode pembelajaran tersebut, maka dapat dipahami bahwa metode pembelajaran Snowball Throwing lebih berhasil dibandingkan dengan metode pembelajaran Talking 
Stick, hal ini dikarenakan metode pembelajaran Snowball Throwing memiliki tujuan dengan melatih peserta didik untuk aktif, kreatif, dan dengan adanya permainan bola salju yang dilakukan selama lima menit menambah antusias peserta didik untuk belajar. Sedangkan pada metode pembelajaran Talking Stick dalam proses pembelajaran peserta didik antusias dengan adanya permainan tongkat bertanya dengan lagu pengiring. Namun berdasarkan hasil dari penelitian Sukawati bahwasannya rata-rata hasil belajar kelas eksperimen I yang menggunakan metode pembelajaran Snowball Throwing lebih tinggi dibandingkan dengan kelas eksperimen II yang menggunakan metode pembelajaran Talking Stick. Sedangkan, penelitian Susilawati (2018) yang menyebutkan bahwa pembelajaran yang menerapkan metode pembelajaran Snowball Throwing peserta didik lebih termotivasi untuk bersaing dan berani mengemukakan pendapatnya sehingga proses pembelajaran yang dilakukan sangat menyenangkan. Sedangkan pembelajaran yang menerapkan metode pembelajaran Talking Stick peserta didik menjadi tegang dan was-was ketika tongkat diputar, sehingga peserta didik bertanya-tanya apakah bisa menjawab pertanyaan dari pendidik atau tidak. Berdasarkan hasil penelitian dari kedua jurnal di atas, maka dapat dipahami bahwa hasil belajar Fisika dengan materi Gerak Lurus kelas X di SMA Negeri 1 Belitang lebih tepat menggunakan metode pembelajaran Snowball Throwing daripada metode pembelajaran Talking Stick, hal ini dikarenakan adanya peningkatan keaktifan belajar peserta didik dari segi kerjasama, bertanya, dan menjawab pertanyaan. Selain itu metode pembelajaran Snowball Throwing sangat berguna untuk menumbuhkan kemampuan berfikir kritis, bekerja sama, dan saling membantu peserta didik lain dalam kelompoknya. Maka wajar apabila hasil penelitian dari peneliti menunjukkan bahwa pembelajaran yang menerapkan metode pembelajaran Snowball Throwing lebih berhasil daripada pembelajaran yang menerapkan metode pembelajaran Talking Stick.

\section{PENUTUP}

Hasil penelitian menunjukkan bahwa terdapat perbedaan hasil belajar Fisika yang signifikan antara peserta didik yang menggunakan metode pembelajaran Snowball Throwing dengan metode pembelajaran Talking Stick pada materi Gerak Lurus kelas x di SMA Negeri 1 belitang tahun pembelajaran 2019/2020. Dibuktikan dengan adanya perbedaan nilai rata-rata kelas eksperimen I lebih tinggi daripada kelas eksperimen II dan peserta didik kelas eksperimen I yang mendapat nilai kategori tinggi lebih banyak daripada kelas eksperimen II.

\section{UCAPAN TERIMAKASIH}

Ucapan terimakasih kepada seluruh civitas akademika SMA Negeri 1 Belitang yang telah berperan serta dalam mensukseskan penelitian ini.

\section{DAFTAR PUSTAKA}

Agustina, E. T. (2013). Implementasi model pembelajaran snowball throwing untuk meningkatkan hasil belajar siswa dalam membuat produk kria kayu dengan peralatan manual. Innovation of Vocational Technology Education, 9(1).

Ansori. (2008). Teori Taksonomi Bloom. Jakarta: Rineka Cipta.

Arikunto, S. (2005). Manajemen Penelitian. Jakarta: Rineka Cipta.

Arsyad, A. (2007). Media Pembelajaran (cetakan kesembilan). Jakarta: PT Raja Grafindo Persada.

Dimyati dan Mudjiono. (2015). Belajar dan Pembelajaran. Jakarta: Rineka Cipta.

Faradita, M. N. (2018). Pengaruh Metode Pembelajaran Type Talking Stick Terhadap Hasil Belajar IPA pada Siswa Kelas 4 Sekolah Dasar. Jurnal Bidang Pendidikan Dasar, 2(1A), 47-58.

Hamalik, O. (2011). Perencanaan Pengajaran Berdasarkan Sistem Pendidikan. Jakarta: Bumi Aksara. 
42 | Titian IImu: Jurnal IImiah Multi Sciences Vol. 12 No. 1, Januari 2020

Hamdayana, J. (2017). Model dan Metode Pembelajaran Kreatif dan Berkarakter. Bogor: Ghalia Indonesia.

Huda, M. (2013). Model-Model Pengajaran dan Pembelajaran. Yogyakarta: Pustaka Pelajar.

Munawaroh, M., \& Alamuddin, A. (2014). Pengaruh Penerapan Model Pembelajaran Snowball Throwing Terhadap Hasil Belajar Matematika Siswa Dengan Pokok Bahasan Relasi Dan Fungsi. EduMa, 3(2), 163-173.

Purbowo, G. A., \& Hendikawati, P. (2012). Keefektifan Pembelajaran Snowball Throwing Berbantuan Lembar Kegiatan Siswa. Unnes Journal of Mathematics Education, 1(1).

Siregar, Eveline dan Hartini, N. (2017). Teori Belajar dan Pembelajaran. Bogor: Ghalia Indonesia.

Slameto. (2010). Belajar dan Faktor-Faktor Yang Mempengaruhi. Jakarta: Rineka Cipta.

Sugiyono. (2009). Metode Penelitian Kuantitatif, Kualitatif, dan R\&D. Bandung: Alfabeta.

Susilawati. S. (2018). Perbandingan Hasil Belajar Siswa Menggunakan Model Pembelajaran Tipe Talking Stick Dan Snowball Throwing Pada Materi Redoks Kelas X MA UNIVA Medan. Cheds: Journal of Chemistry, Education, and Science, 2(1), 56-67.

Yahya, N., \& Nur, M.U.C.H. (2013). Pengembangan Perangkat Model Pembelajaran Kooperatif Tipe Talking Stick Pada Standar Kompetensi Mengoperasikan Peralatan Pengendali Daya Tegangan Rendah Di SMKN 2 Surabaya. Jurnal Pendidikan Teknik Elektro, 2(1). 